\title{
OPINION
}

\section{Family farmers should move toward the animal welfare movement}

\author{
Denny Caneff
}

Can one of agriculture's biggest perceived "threats" actually benefit family farmers? Yes, if it is channelled and directed the right way. The animal welfare "threat" may be the salvation of family farming.

Agriculture's Red Scare. Reading the farm press in Wisconsin, one gets the impression that the biggest threat facing family farmers is the animal rights movement. Youth who exhibit animals at fairs get special training in how to bandle questions from animal rights activists. An agribusiness representative tells a farm audience that the animal rights movement wants to "make vegetarians out of all of us." A University of Wisconsin dairy scientist tells his students that the animal rights issue ranks third on the list of issues that members of Congress hear about from constituents, after Social Security and the economy. An American Farm Bureau Federation spokesman tells a farm audience that animal rights activists are "penetrating" elementary schools with their messages.

Is the animal rights movement really the unstoppable social juggernaut these observers claim? How many animal rights activists have stormed farms to set the Holstein captives free? Or is this agriculture's Red Scare?

Blown out of proportion....for a reason? Most of these critics of the animal welfare movement ignore an important

Denny Caneff is Executive Director, Wisconsin Rura Development Center, 1406 Business Hwy. 16/151 E. Mount Horeb, WI 53572. distinction. The animal rights/liberation/ welfare/protection movement is as diverse as any social movement. I list the various descriptors above for a reason: to animal activists, they connote different philosophies about society's use of animals and different tactics for expressing those philosophies.

At one extreme are animal liberationists, who believe that humans have no right to control the destiny of any animal. The moderate end of the spectrum, in contrast, is represented by the nation's oldest, best-known, "establishment" animal protection organization, the Humane Society of the United States. HSUS resents the blurring of animal welfare ideologies, because such blurring lumps its acceptance of using animals in scientific research and agriculture with the tactics of People for the Ethical Treatment of Animals.

How did animal welfare critics manage to weave this diverse movement into one seamless cut of dangerous cloth? They did it purposely. Many alarms about the animal protection movement (the term that moderates prefer, and the one that I will use) are sounded for farmers. But they are generally sounded by non-farmers: representatives of agribusiness companies, organizations of large-scale farmers, and commodity and livestock promotion groups. These groups need farmers as foot soldiers in their war against any social movement that threatens their primacy in the U.S. food system, including the animal protection movement. The farm and commodity organizations rail against the animal protection movement to distract farm- er-members from recognizing the real threats facing them, many of which those organizations helped create-like the continuing industrialization of animal production.

Animal protection at the factory farm gate. Factory-style livestock production has little to recommend it for family farmers. As farmer-essayist Gene Logsdon wrote (Farm Journal, January 1989), "Which is more of a threat to your independent business as a family livestock farmer: animal rights or animal mega-factories? Think about it." Current trends in livestock agriculture suggest that in the 1990s we will see an accelerated shift of animal production from small, diversified family-operated farms to large-scale, highly mechanized and controlled feedlot and confinement systems.

The industrialization of poultry seems to be paving the way for the industrialization of hog production. Purdue University agricultural economists estimate that $60 \%$ of the nation's hog producers will go out of business in the next eight years; those who survive will produce at least 3,000 hogs per year. Hogs, once family farming's "mortgage burner," will become, like their poultry counterparts, production widgets controlled by a handful of food companies.

Animal factories are vulnerable to the criticisms of animal protectionists. The Humane Farming Association has made a national issue of veal crates, for example. There lies the possibility of alliances be-

continued on $p .46$ 
work on future agriculture policy, and organizing and orchestrating ahead of time.

The policy opportunities and challenges ahead were explored by a panel moderated by Kate Clancy of Syracuse University: Roger Blobaum of Blobaum and Associates; Chuck Hassebrook of the Center for Rural Affairs; Maureen Hinkle of the National Audubon Society; Jim Jontz, former Indiana Congressman; Fred Kirschenmann, farm leader from North Dakota; and Bill Lacy of Pennsylvania State University. They stressed the need for better coalitions, skilled labor, and sustainable communities to reach sustainable agriculture's full potential.

Bob Bergland, former Agriculture Secretary and Executive Vice President and General Manager of the National Rural Electric Cooperative Association, made the closing remarks at the conference, which he had hosted at the NRECA building in Washington, D.C.

\section{IAA Conference Proceedings Now Available}

The proceedings of the 1992 IAA conference, Alternative Farming Systems and Rural Communities-Exploring the Con- nections, are now available for \$6. Included are papers based on the presentations of 15 speakers and five work groups which explored strategies to restore or create healthy connections between agriculture and rural communities. The proceedings are available from the Henry A. Wallace Institute for Alternative Agriculture, 9200 Edmonston Road, \#117, Greenbelt, MD 20770; (301)441-8777.

\section{Farm Groups Urge Clinton to Increase SARE Funding}

Several farm organizations, including the Wallace Institute, have written to President Clinton, urging him to include the SARE program and the Sustainable Agriculture Technology Development and Transfer Program (SATDTP) among the increased research and technology investments presented in the FY'94 budget proposal.

"It is our sincere hope that over the next two or three fiscal years these two programs will reach their fully authorized levels of $\$ 40$ million and $\$ 20$ million, respectively," the groups wrote. The SARE program, they said, "plays a unique and important role in the overall federalstate research arena;" the SATDTP would help train agricultural agents, and "improve outreach and technology transfer to the farm community."

\section{South Dakota State University Economist is Visiting Scholar}

Thomas L. Dobbs, a professor of agricultural economics at South Dakota State University, is spending time at the Wallace Institute this spring studying farm and environmental policies and programs that could foster the sustainability of agriculture. His project, which makes a major contribution to the Institute's new alternative agriculture policy studies program, expands upon his ongoing research on implementation and impacts of federal programs in his region.

Dobbs, who earned a $\mathrm{Ph} . \mathrm{D}$. degree from the University of Maryland, brings to his assignment several years of pioneering research on the economics and policy implications of sustainable farming systems in the Corn Belt-Great Plains. He served for three years on the North Central Administrative Council which directs the USDA's SARE program in that region.

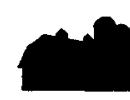

\section{OPINION cont'd from $p .4$}

tween family farmers and animal protectionists. Family farmers can make a convincing case that their farming systems usually offer animal protection benefits that the industrial systems cannot.

Several systems that respect animal protection have been championed by the sustainable agriculture movement. Hog farmers in Iowa are finding outdoor farrowing on pasture and other low-capital production systems profitable and enjoyable-for them and their hogs. University of Minnesota researchers have confirmed this, finding low-input hog production as productive as confinement, while requiring less capital and work for the farmers, and improving the hogs' welfare.

Dairy farmers in Wisconsin find that intensive rotational grazing benefits the land, their profits, and their cows' comfort and productivity. A University of Wisconsin meat scientist found that compared with formula-fed veal, grain-fed veal was cheaper to raise, as palatable, and as productive. Most important, the veal calves did not require the confinement crates that are vilified by animal protectionists.

Real animal protection at the family farm gate. Clearly, there are workable, profitable alternatives to animal factories that will benefit farmers, their customers, and their animals. Farmers need to adopt and promote these systems to demonstrate how they benefit animal welfare-and their own profits. Farmers also need to direct animal protectionists' sweeping criticisms to the corner where their critical brooms should be aimed-the animal factories.

For their part, animal protectionists need to differentiate between the positive animal welfare benefits possible (but not always present) on small and mediumsized family-operated farms, and the absence of those benefits in animal factories. There is precedent for collaborating with farmers on this issue. The Humane Society brought in livestock farmers to help it develop its "recommended humane principles" for livestock production. The Animal Welfare Institute worked with southern Minnesota hog farmers to develop a humanely raised pork product for direct marketing to consumers.

This is the kind of alliance that farmers must make with animal protectionists, environmentalists and others if they, not food conglomerate stockholders, are to be beneficiaries of livestock agriculture. 